\title{
UF

\section{A Guide to Authorizing and Chartering 4-H Clubs or Affiliated Groups and Requirements for Tax-Exempt Status ${ }^{1}$}

Marilyn Norman and Joy C. Jordan ${ }^{2}$

Any formally or informally organized entity using the 4-H Name and Emblem must have some type of written evidence that recognizes it as part of the 4-H program conducted by the Cooperative Extension Service. National 4-H Headquarters at USDA CSREES has identified three distinct groupings for 4-H programs to use when granting such authorization and approvals. There is a specific method for granting authorization and the associated rights and responsibilities to each group.

The three groups are:

- 4-H Programs through organized 4-H clubs (any type or location) or other special interest groups or camps.

- Affiliated organizations that provide support to the 4-H Program, such as advisory committees, councils, foundations, boards, or other partnering agencies.

- Vendors or other entities who are producing a product or service for the $4-\mathrm{H}$ Program.

The respective methods to use in granting authorization are 1) 4-H programs and clubschartering; 2) affiliated groups - memoranda of understanding (MOU); and 3) vendors or service Providers-letters of authorization.

${ }^{1}$ This document is 4-HS FS 2.5/4H263, one of a series of the Florida 4-H Program, Florida Cooperative Extension Service, Institute of Food and Agricultural Sciences, University of Florida. First published January 2008. Please visit the 4-H Website at http://4h.ifas.ufl.edu/Curriculum/index.htm.

2 Marilyn Norman, associate professor, and Joy C. Jordan, associate professor, Department of Family, Youth and Community Sciences, Institute of Food and Agricultural Sciences, University of Florida, Gainesville, FL 32611. 


\section{Chartering 4-H Clubs or Groups}

Chartering means that the Cooperative Extension System recognizes these entities as "4-H" and:

- includes them under our tax ID;

- accepts responsibility for them;

- expects these entities to be accountable and compliant with all applicable policies.

4-H Charters, either in certificates or letter form, are required for any 4-H Club/Group to 1) use the 4-H Name and Emblem and 2) be included in the tax-exempt status of 4-H. Such evidence should include:

$>$ For clubs/groups, a copy of an application or request form sent to the local Extension agent; and

$>$ a written reply from the local Extension agent, including the club's charter certificate, recognizing the club or group as an official 4-H organization and authorizing use of the 4-H Name and Emblem.

All charters must be the National 4-H Headquarters-USDA approved charter certificates issued at the state 4-H office. The Extension Director or State 4-H Program Leader makes all decisions regarding who shall receive a charter, when charters need to be renewed, and when to revoke a charter.

\section{Criteria for Chartered 4-H Clubs in Florida}

Florida has established criteria for enrolling as an official 4-H Club. Clubs must formally request to be chartered through the local Extension office and must meet the minimum criteria for a $4-\mathrm{H}$ Club-listed below. Official enrollment as a 4- $\mathrm{H}$ club / receipt of a 4-H club Charter gives the club the authority to use the 4-H Name and Emblem. In order for a group to be enrolled as an official club:

- The club must have five members (from at least two families) with completed enrollments.

- The club must be organized with youth officers/youth in leadership roles.

- There must be one or more appointed and trained club leaders.

- An initial meeting place must be secured for at least three meetings.

- An official non-discriminatory club name must be chosen.

- Club rules, which may be in the form of by-laws, must be established.

- At least six or more regular meetings, plus project meetings, must be scheduled.

- A written educational plan for the club program and activities must be presented to the county 4-H office (a draft is okay).

\section{New Club Procedures:}

A new club must complete the New 4-H Club Charter Application form and the volunteersigned Annual Charter Request Form and submit these along with their club program plan/calendar, a list of club enrollment with identified officers, and a copy of their proposed by-laws. These materials are kept on file with the local 4-H office.

When requesting a Club Charter, the $\mathrm{New}$ 4- $\mathrm{H}$ Club Charter Application should be filled out by the club secretary and signed by the club president, club leader, and Extension agent. The Annual Charter Request Form should be completed and signed by the club leader and the Extension agent. Once these are completed, the Extension Agent will forward a copy of the application/request forms to the State 4-H Office.

\section{All Existing Clubs:}

Individual clubs may have continuous use of their charter over many years; however, an Annual Request for Continuance is required from all clubs, signed by one organizational volunteer.

Again, this form is kept on file with the local 4H office.

\section{What If I Have NOT Been Chartering Clubs in the Past?}

First, club leaders should determine if they have a Certificate of Charter. Review the criteria to maintain a charter with leaders.

To maintain a county roster of all chartered 4-H clubs and to issue National Certificates of Charter, the State 4-H Office needs a complete roster of all existing 4-H clubs that need National Certificates 
of Charter (if they have not received one in the past).

Each existing club leader should complete the Annual Request for Continuance in order to be included on this roster. The letter of request for Certificates of Charter for existing clubs can be sent immediately to the State 4-H Office. Please include the names of the clubs and the year of origination for each club, if possible. After this process of "catching up," the Annual Renewal Request/New 4-H Club Applications for Charter should be instituted and maintained.

\section{What If They Meet All the Criteria But the Club Name Seems to Be of Concern?}

Potentially discriminatory $4-\mathrm{H}$ club names have been an issue in the recent past, especially since many county staff are completing the official chartering process for clubs that have existed for some time. The State 4-H Office does review the names of NEW clubs before granting approval for a charter. This will also be done as we receive the rosters of existing clubs. Naming a club, or changing the name, to be in compliance with the state criteria will be necessary to be officially chartered and sanctioned to use the Name and Emblem. EDIS publication 4HS FS101.7, "Naming a 4-H Club," addresses these concerns and can help clubs to think about their choices.

\section{Maintaining and Updating Club Files Annually}

Presuming there are no other issues of noncompliance, written notice of charter renewal will be provided annually to each 4-H club once the Annual Request for Chartership is signed and returned. Paperwork need only be sent to the State 4-H Office for new club formation.

In addition to the Annual Request for CharterRenewal, current files should be maintained on each club/officially organized 4-H group.

Annually, club files should be updated with 1) the club enrollment/roster of youth/volunteers; 2) a list of officers; 3) program plans/calendars and schedule of meetings/dates; and 4) by-laws (when changes occur).

\section{Checklist for Obtaining a New Club Charter} The following checklist can serve as a reference for new clubs who need to obtain a Charter. It may take two or three organizational meetings to complete the requirements for a club Charter for a new club.

1- Club completes the New 4-H Club Charter Application \& Annual Request Form with support documentation and submits to the 4-H Agent for review.

2- Agent forwards copy of signed Charter Application/ Request Form only to the State 4-H Office-upon approval, it is entered into a state club database.

3- County Office creates and maintains a file for each chartered club that includes their application with supporting documents (club plan and calendar, listing of officers, etc.) to be updated from year to year.

4- Once the state has approved the request, a charter certificate will be sent to the 4-H Agent.

5- The 4-H Agent sends a charter certificate and letter acknowledging status to the club president/leaders, authorizing their use of the Name and Emblem and informing them of 4-H rights and responsibilities.

6- 4-H Agent checks the box on their club screen in the enrollment database indicating that the club is chartered.

7- The agent helps the club obtain an EIN number if there is to be a club treasury. Once this has occurred, the agent sends a letter to the IRS adding new clubs to IRS database for listing on the public charities tax-exempt publication.

\section{Yearly Maintenance of Club/Group Charters:}

1- Annually, the established 4-H club completes the Annual Charter Request Form. This should be signed by the organizational volunteer leader and submitted to the 4-H Agent along with, or prior to, club program plans, calendar, and youth enrollments.

2- The agent updates the club file with these documents. These forms are maintained in the county office and not resubmitted to the state office.

3- The agent provides written notification of the club's continuous status. 


\section{Other Affiliate 4-H Groups}

Any 4-H entity that uses the 4-H Name or Emblem fits into this group. This could be a formal group like a County 4-H Advisory Board, a County 4-H Foundation, or a 4-H Youth or Leaders' Council, or it could be a Livestock/Clothing Project Committee that seeks donations and funds to support project training in a specific 4-H project. It may also include schools, after-school sites, or day camps sponsored by an organized community group.

All these groups must be sanctioned as official entities in order to use the 4-H Name and Emblem and receive tax-exempt status for 4-H related activities. A written memorandum of understanding (MOU) with them must confirm their status. The MOU will outline that these groups must be non-discriminatory in their policies and actions and open to all youth. They must follow all state $4-\mathrm{H}$ policies and guidelines, and maintain the responsibilities associated with the 4-H Name and Emblem use. Additional expectations of the Extension Service/4-H and the affiliate group will be written in the MOU.

As with vendors and service providers, there is a hierarchy of who can issue the authorization. Affiliate groups operating beyond the county level must receive authorization from the State $4-\mathrm{H}$ Youth Development Office. Those operating beyond the state level must have national authorization.

\section{Tax-Exempt Status of Chartered Clubs/Affiliate Groups}

Upon chartering a 4-H club or creating a memorandum of understanding (MOU) with a 4-H affiliate group, groups may have tax-exempt status under the National 4-H Group Exemption Number (GEN) related to their 4-H activities. However, to use this number, and for the IRS to recognize their status, the group must be a part of a national database of officially chartered or sanctioned 4-H groups. Any club or affiliated group that seeks funds or in-kind gifts from businesses or donors must first obtain an EIN or Federal Tax Identification Number. This can be done online at http://www.irs.gov using form SS-4.

Once these groups have secured their own EIN, the County Agent should prepare a letter to the IRS submitting the group name, mailing address, the GEN (2704), the EIN number; and the date to be included (use a consistent date annually-e.g. November 1). A sample of a letter is provided on the faculty and staff $4-\mathrm{H}$ website.

For further resources and guides to tax-related procedures for 4-H Clubs and Affiliate Groups, refer to the 4-H Financial Management Fact Sheets (4H 5.1 - 4H 5.8) or Section 5 of the Florida 4-H Program Handbook under "Faculty and Staff" at the Florida 4-H Web site: http://www.Florida4H.org. 